\title{
PENINGKATKAN HASIL BELAJAR MATEMATIKA MELALUI METODE DRILL DAN DISKUSI KELOMPOK PADA SISWA KELAS VI SD
}

\author{
Erlyn Juniati \\ erlynjuniati12@gmail.com \\ SD N I Badran Kranggan Temanggung.

\section{EFFORTS TO INCREASE MATHEMATICS LEARNING RESULTS THROUGH DRILL METHOD AND GROUP DISCUSSION IN GRADE CLASS VI ES}

\begin{abstract}
One of the main problems of today's Mathematics Lesson is the lack of understanding and motivation of teachers in schools, so that children are less active in the learning process. This phenomenon occurs in SD N I Badran. Based on the results of formative tests of class VI semester 2 subjects mathematics of the material change the common fractions into decimal fractions and percent or otherwise low, this is validated by the analysis of the average grade 58, 33. Of the 30 students who achieve the value of learning mastery only 11 students, The rest is still far below KKM ( $\leq 70)$. Students do not yet understand in changing the usual fractions to decimal fractions and percent or vice versa. This type of research is Classroom Action Research. The subjects studied were the 6th graders of SD Negeri I Badran, Kranggan Sub-district, Temanggung Semester 2 of the 2015/2016 Lesson Study. This study was conducted in 2 cycles, each cycle consisting of 3 meetings, and each cycle consisted of planning, action, observation and reflection. From the result of research by using Drill method and group work, there is an increase of student learning result. In learning mathematics subject matter converts the usual fractions into decimal fractions and percent and vice versa. Prior to the improvement of the number of 30 students who thoroughly studied with KKM 70 only 11 students, with an average score of 58, 33 with mastery learning 36, 66. Improvement of learning Cycle 2 first meetings average grade 83.33 complete 25 percentage of mastery $83.33 \%$. The researcher concludes that the result of the study of the sixth graders of SD Negeri 1 Badran of Kranggan Sub-district of Temanggung Regency on the subject changed the common denominations to decimal and percent and vice versa through Drill method and Group Discussion of learning result increased.
\end{abstract}

Keywords: Active, critical thinking, Mathematics learning outcomes, Drill Methods and group discussions.

\section{Article Info}

Received date: 2 Agustus $2017 \quad$ Revised date: 28 Agustus $2017 \quad$ Accepted date: 18 September 2017

\section{PENDAHULUAN}

Matematika merupakan ilmu universal yang mendasari perkembangan teknologi modern, mempunyai peran penting dalam berbagai disiplin dan memajukan daya pikir manusia. Perkembangan pesat dibidang teknologi informasi dan komunikasi dewasa ini dilandasi oleh perkembangan matematika dibidang teori bilangan,aljabar,analisis,teori peluang dan matematika diskrit. Untuk menguasai dan menciptakan teknologi dimasa depan diperlukan penguasaan matematika yang kuat sejak dini.

Guru harus memiliki pengetahuan dan pemahaman yang tinggi dalam berbagai aspek. Tuntutan semacam itu tidak dapat ditawar-tawar lagi, karena perubahan gaya belajar peserta didik yang begitu kompleks. Peserta didik merasa dirinya telah dibekali dengan sejumlah potensi sejak lahir, maka seorang pendidik harus peka terhadap dinamika yang dialami oleh anak didiknya. Episode belajar yang direncanakan harus mampu meningkatkan tingkat atau taraf belajar siswa, oleh karena itu seorang pendidik harus menyiapkan perangkat belajar yang mudah dicerna, fleksibel dan dapat dipelajari serta dimanfatkan oleh peserta didik dimanapun dan kapanpun juga. 
Kenyataan di lapangan menunjukkan bahwa pembelajaran matematika di SD masih bersifat konvensional. Guru kurang memberi motivasi, sehingga siswa kurang paham dengan materi yang disampaikan. Sehinggan siswa kurang aktif, dalam mengikuti pembelajaran, kurang memaksimalkan kelompok belajar, dan kurang telatennya berlatih secara berulang - ulang serta pemilihan metode yang kurang tepat. Sehingga mengakibatkan rendahnya pemahaman siswa dalam mencerna pada mata pelajaran matematika materi mengubah pecahan biasa menjadi pecahan desimal dan persen serta sebaliknya. Hal ini terbukti hasil belajar matematika kelas VI SD Negeri I Badran rendah. Dari jumlah siswa 30 yang nilainya tuntas hanya 11 siswa,, banyak siswa yang nilainya di bawah KKM. Hasil rata - rata kelas 58, 33. Menyimak realita tersebut maka penulis tertarik untuk mengadakan suatu pembelajaran melalui penelitian tindakan kelas dengan judul " Upaya meningkatkan Hasil Belajar Matematika melalui Metode Drill dan Diskusi Kelompok pada SD Negeri I Badran Tahun Pelajaran 2015/ 2016".

Berdasarkan latar belakang masalah di atas sebagai berikut: 1) Apakah penggunaan metode drill dan diskusi kelompok dapat meningkatkan hasil belajar Matematika pada siswa kelas VI SD N 1 Badran Tahun 2015/ 2016?. 2) Seberapa besar peningkatan hasil belajar Matematika melalui metode drill dan diskusi kelompok pada siswa kelas VI SD N 1 Badran tahun pelajaran 2015/ 2016?

Berdasarkan rumusan masalah di atas dapat disusun tujuan penelitian ini sebagai berikut: 1) Tujuan umam, a) Meningkatkan pemahaman siswa dalam mencerna pelajaran melalui metode Drill dan Diskusi Kelompok b) Meningkatkan keaktifan siswa melalui metode Drill dan Diskusi Kelompok.c) Meningkatkan hasil belajar matematika melalui metode Drill dan Diskusi Kelompok. Berdasarkan tujuan di atas dapat dipaparkan manfaat penelitian ini sebagai berikut: 1) Manfaat bagi siswa: a) Melalui metode Drill dan Diskusi Kelompok diharapkan dapat meningkatkan pemahaman belajar siswa khususnya kelas VI b) Meningkatkan keaktifan siswa c) Melatih berani siswa untuk mengeluarkan pendapat dan menyampaikan pertanyaan. d) Meningkatkan hasil belajar siswa. 2) Manfaat bagi guru: a) Berguna untuk menentukan metode pembelajaran yang sesuai untuk meningkatkan hasil pembelajaran yang dapat mengembangkan potensi siswa secara optimal. b) Dapat memperoleh informasi seberapa besar pengaruh yang dihasilkan dengan adanya suatu proses perbaikan pembelajaran yang di berikan kepada siswa.3) Manfaat bagi Sekolah: a) Sebagai masukan dan referensi tambahan pendukung bagi rekan guru SD, bahwa pada mata pelajaran matematika perlu adanya suatu penerapan metode-metode yang tepat dalam meningkatkan proses pembelajaran.b) sebagai sumbangan pemikiran dalam usaha-usaha yang mengarah pada peningkatan kemampuan guru dalam memecahkan masalah pembelajaran.

\section{KAJIAN PUSTAKA}

Belajar adalah suatu proses yang kompleks yang terjadi pada semua orang dan berlangsung seumur hidup. Salah satu tanda bahwa seseorang telah belajar sesuatu adalah adanya perubahan tingkah laku dalam dirinya. Perubahan tingkah laku tersebut menyangkut perubahan yang bersifat pengetahuan dan keterampilan maupun yang menyangkut nilai dan sikap (Sadiman, 2003).

Muhammad Ali (1992) mengemukakan bahwa "mengajar adalah segala upaya yang disengaja dalam rangka memberi kemungkinan bagi siswa untuk terjadinya proses belajar sesuai tujuan yang dirumuskan". Sasaran akhir dari proses pembelajaran adalah siswa belajar dengan upaaya yang disengaja dan penuh rasa tanggung jawab untuk mencapai tujuan. Tujuan tercapai melalui proses pembelajaran, sedangkan belajar bisa terjadi dengan berbagai cara. Bisa dengan cara langsung mengajar di kelas atau dengan alat pembelajaran.

Kegiatan belajar mengajar adalah suatu kondisi yang dengan disengaja diciptakan, gurulah yang menciptakannya, guru membelajarkan anak didik. Guru yang mengajar dan anak didik yang belajar. Perpaduan dari kedua unsur manusiawi ini lahirlah interaksi edukatif dengan memanfaatkan bahan sebagai mediumnya. Semua komponen pengajaran diperankan secara optimal guna mencapai tujuan yang telah ditetapkan sebelum pengajaran dilaksanakan (Djamarah dan Zain, 2002).

Berdasarkan pengertian belajar mengajar dapat diketahui bahwa proses belajar mengajar merupakan suatu proses yang mengandung serangkaian perbuatan guru dan siswa atas dasar hubungan timbal balik yang berlangsung dalam situasi edukatif untuk mencapai tujuan tertentu. Dalam proses belajar mengajar tersebut terdapat adanya suatu kesatuan yang tidak dapat dipisahkan antara guru dan siswa yang belajar, antara kedua kegiatan ini terdapat interaksi yang saling menunjang (Usman, 1995). Chatarina Tri Anni (2007) menjelaskan bahwa hasil belajar merupakan 
perubahan tingkah laku yang diperoleh pembelajar. Hasil belajar dapat ditingkatkan melalui usaha sadar yang dilakukan secara sistimatis mengarah kepada perubahan yang positif yang kemudian disebut proses belajar. Akhir dari proses belajar adalah perolehan suatu hasil belajar. Hasil belajar di kelas terkumpul dalam himpunan hasil belajar kelas. Semua hasil belajar tersebut merupakan hasildari interaksi tindak belajar di akhiri dengan proses belajar, sedangkan dari sisi siswa, hasil belajar merupakan beakhirnya penggal dan puncak proses belajar (Dimyati dan Mudjiono, 2009)

Menurut Nana Sudjana (2005) Hasil belajar adalah perubahan tingkah laku siswa setelah melalui proses pembelajaran. Semua perubahan dari proses belajar merupakan suatu hasil belajar dan mengakibatkan manusia berubah dalam sikap dan tingkah lakunya. Dari pendapat di atas dapat disimpulkan hasil belajar adalah hasil yang dicapai oleh seseorang siswa setelah melakukan usaha sehingga adanya perubahan atau peningkatan yang lebih baik di bandingkan sebelumnya.

\section{Metode Tanya jawab (Drill)}

Metode Tanya jawab ini dapat diartikan sebagai format interaksi antara guru dengan siswa melalui kegiatan bertanya yang dilakukan oleh guru dengan tujuan untuk mendapatkan respon dari siswa, sehingga dapat menumbuhkan pengetahuan baru bagi siswa. Adapun kelemahan dan keunggulan dari metode tanya jawab ini adalah sebagai berikut (Elypita Elly, 2013): Keunggulan metode Tanya jawab adalah seperti berikut ini. 1) Guru dan siswa sama-sama aktif dalam proses pembelajaran 2).Mendorong minat siswa dalam proses belajar mengajar 3) Membimbing pemikiran yang sistematis, kreatif dan kritis dalam pembelajaran 4) Mengembangkan kemampuan untuk menyatakan pendapat pada diri siswa 5) Memberikan kesempatan pada diri siswa menggunakan pengetahuan sebelumnya untuk belajar sesuatu yang baru. Sedangkan kelemahan dari metode Tanya jawab antara lain: 1)Keaktifan siswa dominan tergantung pada keaktigfan guru 2). Keberhasilan siswa tergantung pada keaktifan guru terhadap teknik-teknik bertanya dan jenis pertanyaannya.

Langkah-langkah metode drill menurut Roestiyah (Sari, Noviyana, and Maryatun, 2016) adalah sebagai berikut: 1). Gunakan latihan ini hanya untuk mata pembelajaran yang dilakukansecara otomatis, tanpa menggunakan pemikiran yang dan pertimbangan yang mendalam. Tetapi dapat dilakukan dengan cepat seperti gerak reflekss. Misal, menghafal, menghitung,dan sebagainya. 2). Guru harus memilih latihan yang mempunyai arti luas yang dapat menanamkan pengertian pemahaman akan makna dan tujuan latihan sebelum mereka melakukan. Sehingga latihan mampu menyandarkan siswa akan kegunaan bagi kehidupannya saat sekarang ataupun masa yang akan mendatang. 3). Guru harus menekankan diagnosa, karena latihan permulaan belum bisa mengaharapkan siswa mendapatkan keterampilan yang sempurna. Pada latihan berikutnya guru meneliti hambatan yang timbul dan dialami peserta didik, sehingga dapat memilih atau menentukan latihan mana yang perlu diperbaiki. 4). Perlu mengutamakan ketepatan, dan memperhatikan kecepatan agar peserta didik melakukan kecepatan dan ketrampilan menurut waktu yang telah di tentukan. 5). Guru memperhatikan waktu ketika latihan agar tidak terlalu lama dan tidak terlalu singkat, karna jika terlalu lama akan membosankan. Masa latihan itu harus menyenangkan dan menarik sehingga menimbulkan optimisme dan rasa gembira yang bisa menghasilkan ketrampilan yang baik. 6). Guru dan siswa mengutamakan proses-proses yang esensial/yang pokok dan tidak terlibat pada hal-hal yang tidak diperlukan. 7). Guru perlu memperhatikan perbedaan individual siswa, sehingga kemampuan dan kebutuhan masingmasing siswa dapat berkembang. 8). Guru dan peserta didik menyimpulkan dari hasil latihan.

\section{Metode diskusi}

Gagne dan Berliner (Moedjiono, 1991) mengemukakan bahwa dalam metode diskusi sungguh terbuka atau bervariasi pengertiannya. Gilstrap dan Martin (Moedjiono, 1991) mengutarakan bahwa metode diskusi merupakan materi dimana sejumlah orang membicarakan secara bersama-sama melalui tukar pendapat tentang suatu topik atau pokok bahasan masalah untuk memecahakan dan mencari jawaban dari suatu masalah berdasarkan semua fakta yang memungkinkan untuk itu. Metode diskusi juga diartikan suatu penguasaan isi pelajaran melalui wahana tukar pendapat berdasarkan pengetahuan dan pengalaman yang diperoleh guna memecahkan suatu masalah (Depdikbud, 1986 b: 9).

Adapun keunggulan dari metode diskusi adalah: 1) Memberikan kesempatan kepada siswa untuk berpartisipasi secara langsung 2) Digunakan secara mudah sebelum, selama ataupun sesudah 
metode-metode yang lain 3) Meningkatkan berfikir kritis, partisipasi demokratis, mengembangkan sikap, motifasi serta kemampuan berbicara 4) Memberikan kesempatan kepada siswa untuk menguji, mengubah dan mengembangkan pandangan, nilai dan keputusan yang dipertimbangkan dalam kelompok. 5) Membutuhkan kemampuan para siswa yang lemah dalam pemecahan masalah. Kelemahan metode diskusi antara lain: 1) Sulit untuk diramalkan hasilnya 2) Kurang efisien dalam penggunaan waktu 3) Tidak menjamin penyelesaian, hal ini disebabkan keputusan yang dicapai belum tentu dilaksanakan 4) Cenderung sering di dominasi oleh seseorang atau beberapa orang anggota diskusi 5) Membutuhkan kemampuan berdiskusi dari para peserta agar dapat berpartisipasi secara aktif dalam diskusi.

Langkah-langkah metode diskusi kelompok menurut Winarno Surachmad (Mulyati, S., 2016) adalah seperti berikut: Membentuk kelompok, Guru menjelaskan konsep permasalahan yang harus dipecahkan kelompok. Setiap kelompok menginventarisasi/ mencatat alternatif jawaban hasil didiskusikan. Guru dan siswa membuat kesimpulan atau guru melengkapi jawaban siswa, sampai materi pelajaran tuntas.

Berdasarkan uraian beberapa metode yang diterapkan dalam proses pembelajaran di atas, penulis mengambil salah satu langkah/ alternatife yang dipergunakan untuk memecahkan masalah dalam proses pembelajaran matematika sub pokok bahasan mengubah bentuk pecahan menjadi bentuk desimal melalui metode Tanya jawab (drill) yang terjadi pada siswa kelas VI.

Berdasarkan kajian teori di atas, dapat digambarkan dengan skema kerangka berfikir (penelitian) sebagai berikut:

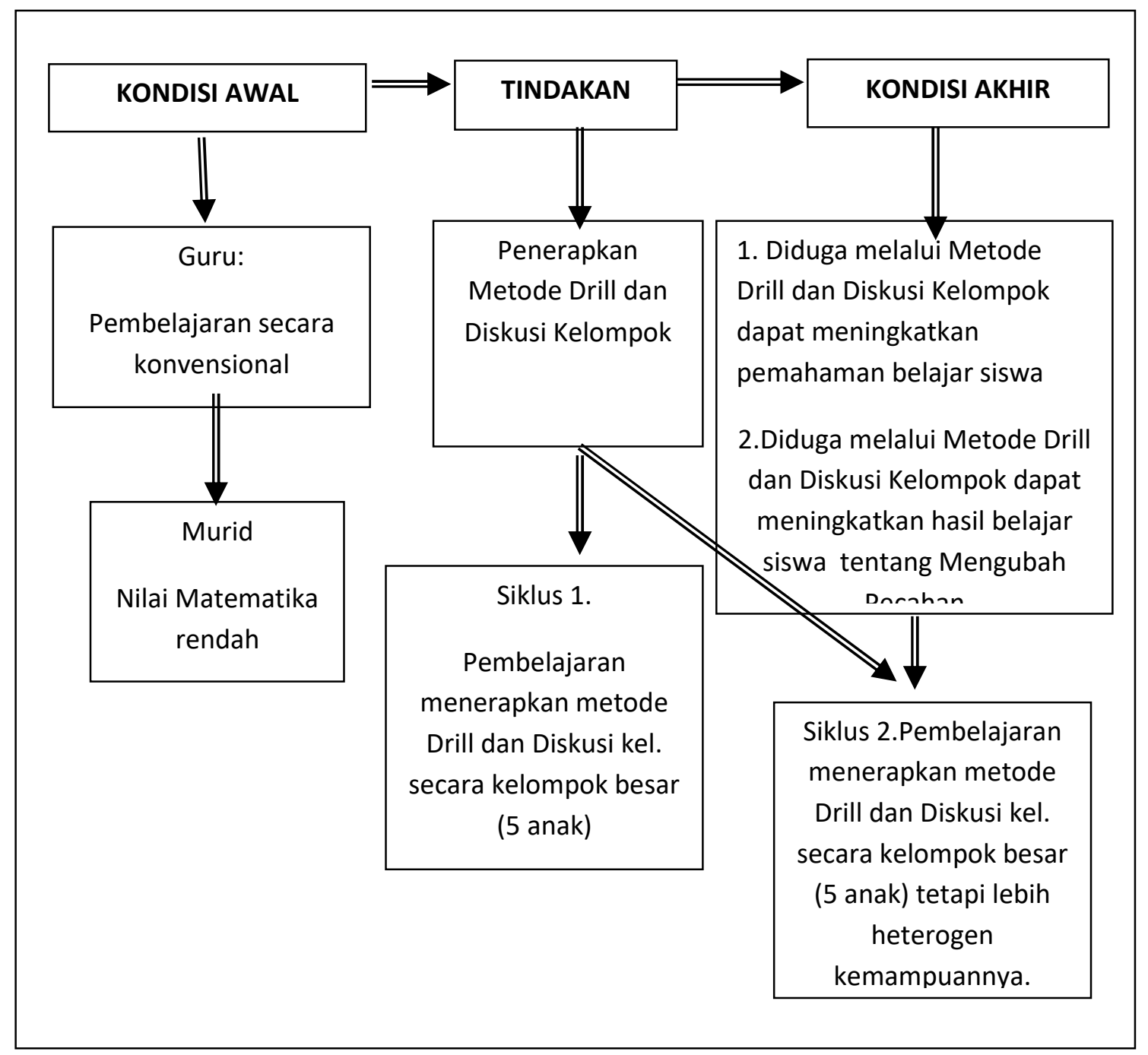

Gambar 1

Kerangka Berpikir 


\section{METODE PENELITIAN}

Penelitian Tindakan Kelas ini dilaksanakan di kelas VI SD Negeri I Badran kecamatan Kranggan Kabupaten Temanggung yang dimulai tanggal 22 Pebruari 2016 sampai 7 Maret 2016. Kegiatan penelitian ini dilaksanakan dengan maksud memperbaiki hasil belajar matematika dengan menggunakan Metode Drll dan Belajar Kelompok. Siswa kelas VI yang berjumlah 30 anak, terdiri dari 16 laki - laki dan 14 perempuan dengan karakteristik kecerdasan siswa $25 \%$ baik, $25 \%$ sedang dan $50 \%$ rendah. Sumber data pada penelitian ini adalah siswa kelas VI SD Negeri I Badran dan guru kelas tersebut yang pengumpulan datanya dilakukan dengan menggunakan instrumen yang sekaligus difungsikan untuk mengetahui ketercapaian indikator kinerja.Instrumen tersebut dimaksud 1.Rendahnya pemahaman siswa 2 . Rendahnya nilai siswa pada pelajaran matematika 3 . Nilai hasil ulangan akhir semester 3.Lembar pengamatan siswa; 4. Lembar pengamatan kegiatan pembelajaran; 5. Angket untuk guru kelas/ peneliti; dan 5. Dokumen-dokumen pembelajaran lain (foto-foto kegiatan).

Data yang diambil dilakukan dengan cara test (proses pelaksanaan pembelajaran berlangsung) dan non test (test pengamatan pelaksanaan pembelajaran dengan pemberian metode): 1) Tes Teknik tes digunakan untuk mengetahui tingkat keberhasilan belajar siswa dalam memperoleh pembelajaran dari teman sendiri melalui kerja kelompok dan test pada akhir pembelajaran berlangsung secara individu.2) Non Tes,Teknik Non Tes yang digunakan dalam penelitian ini, antara lainObservasi (pengamatan), teknik ini digunakan oleh kolaborator untuk mengobservasi pelaksanaan tindakan yang dilakukan oleh peneliti.Validasi data penelitian dilakukan dengan cara trianggulasi data, yaitu dengan menggunakan berbagai data perolehan baik melalui angket, hasil tes, dan hasil pengamatan. Berbagai data tersebut kemudian diolah dengan statistik deskriptif. Penwlitian ini dikatakan berhasil yang dperoleh siswa minimak KKM 70. Dalam pelaksanaan perbaikan pembelajaran untuk meningkatkan efektifitas hasil belajar siswa, maka peneliti mengembangkan rencana penelitian tindakan kelas berupa prosedur kerja yang dilaksanakan didalam kelas.Penelitian ini terdiri dari dua siklus, yaitu masing-masing siklus terdiri dari perencanaan, pelaksanaan, tindakan, pengamatan, dan refleksi.

\section{HASIL PENELITIAN DAN PEMBAHASAN}

Peneliti menerapkan metode Drill dan Diskusi dalam kegiatan pembelajaran. Kegiatan pembelajaran dilaksanakan dalam 2 siklus. Setiap siklusnya melakukan 3 kali pertemuan. Tujuan dengan adanya tahapan-tahapan (siklus) dalam pembelajaran yang peneliti kajikan disini sebagai bahan memperluas dan membuka kesempatan siswa dalam mengembangkan potensi yang dimiliki dan meningkatkan hasil belajarnya.

\section{Pelaksanaan Pembelajaran menggunakan Metode Drill dan Diskusi Kelompok pada Siklus 1}

Dalam pelaksanaan perbaikan pembelajaran untuk meningkatkan efektifitas hasil belajar siswa, maka peneliti mengembangkan rencana penelitian tindakan kelas berupa prosedur kerja yang dilaksanakan didalam kelas.Penelitian ini terdiri dari dua siklus, yaitu masing-masing siklus terdiri dari perencanaan, pelaksanaan, tindakan, pengamatan, dan refleksi.

Pertama-tama mengidentifikasi masalah dan perumusan masalah. Guru berkolaborasi denganteman sejawat untuk mengungkapkan dan memperjelas permasalahan yang dihadapi, untuk dicarikan jalan keluar yang tepat sampai diperoleh hasil yang memuaskan. Guru membuat rencana perbaikan pembelajaran yang berupa scenario pembelajaran/ langkah-langkah pembelajaran, penekanannya pada penggunaan melalui metode drill dan diskusi kelompok. Guru menyiapkan alat peraga yang diperlukan dalam bentuk bilangan pecahan dan persen, yang mendukung materi pelajaran. Guru menyusun alat observasi sebagai panduan bagi pengamat dalam mengamati pelaksanaan proses perbaikan pembelajaran. Guru merancang alat evaluasi yang berupa tes formatif.

Pada tahap ini guru melaksanakan perbaikan pembelajaran sesuai dengan scenario pembelajaran yang telah dibuat sebagai berikut: memfokuskan perhatian dan memotivasi siswa, apersepsi, informasi kompetensi dasar, manfaat materi bahan ajar, serta rencana aktivitas pembelajaran. Guru menyiapkancontoh - contoh soal yang berhubungan dengan pecahan biasa, pecahan desimal dan persen. Siswa menanggapi contoh tersebut melalui tanya jawab lisan. Guru mengajak siswa untuk bersama - sama menyelesaikan soal - soal yang berhubungan dengan materi di papan tulis, serta 
memperlihatkan cara menyelesiaknnya. Guru meminta kepada siswa untuk menuliskan jawaban tersebut di papan tulis. Dengan pengarahan dari guru siswa dibimbing untuk memilih penyelesaian soal yang tepat dan menyempurnakan jawaban-jawaban siswa pada papan tulis. Secara berulang ulang guru dan siswa bertanya jawab materi soal. Guru memberi kesempatan kepada siswa untuk mengerjakan soal - soal secara bergiliran.

Pada tahap ini peneliti melakukan kerjasama dengan teman sejawat untuk mengkaji semua temuan, baik kekurangan maupun kelebihan proses perbaikan pembelajaran siklus 1. Guru sudah menerapkan penggunaan metode drill dan diskusi kelompok. Guru belum menggunakan media pembelajaran yang bervariasi, sehingga penjelasan guru masih verbalisme. Peran guru masih terlalu dominan dalam proses pembelajaran tetapi siswa sudah terlibat aktif dalam proses pembelajaran. Sebagian besar siswa sudah ada perubahan hasil belajar. Selanjutnya, hasil dari refleksi siklus 1 tersebut peneliti pergunakan untuk menyusun langkah-langkah perbaikan pembelajaran siklus 2 .

\section{Pelaksanaan Pembelajaran menggunakan Metode Drill dan Diskusi Kelompok pada Siklus 2}

Berdasarkan hasil refleksi terhadap proses perbaikan siklus I, peneliti menyusun rencana perbaikan pembelajaran siklus II yang terdiri dari empat tahap, yaitu perencanaan, pelaksanaan, pelaksanaan, pengamatan, dan refleksi.

Pada siklus 2 guru melaksanakan perbaikan pembelajaran sesuai dengan scenario pembelajaran yang telah dibuat sebagai berikut: guru memfokuskan perhatian dan memotivasi siswa, apersepsi, informasi kompetensi dasar, manfaat materi bahan ajar, serta rencana aktivitas pembelajaran. Guru menyiapkanlebih banyak contoh - contoh soal yang berhubungan dengan pecahan desimal dan persen. Siswa menanggapi contoh tersebut melalui tanya jawab lisan dan dilakukan secara berulang ulang. Guru mengajak siswa untuk bersama - sama menyelesaikan soal - soal yang berhubungan dengan materi pelajaran. Guru meminta kepada siswa untuk menuliskan jawaban tersebut di papan tulis. Dengan pengarahan dari guru siswa dibimbing untuk menyelesaikan soal - soal yang berhubungan dengan materi, dan menyempurnakan jawaban-jawaban siswa pada papan tulis. Secara berulang - ulang guru dan siswa bertanya jawab materi soal. Guru memberi lembar tugas kepada siswa untuk mengerjakan soal - soal secara berkelompok. Setiap kelompok mempresentasikan hasil kerjanya. Dari hasilkerja kelompok guru mengarahkan dan membimbing siswa menyelesaikan soal soal cecara berulang - ulang. Guru memberi penguatan dan meluruskan soal - soal yang dianggap kurang tepat.

Setelah melaksanakan perbaikan pembelajaran pada siklus 2 peneliti bekerjasama dengan teman sejawat dalam melakukan refleksi diri. Dan dari hasil diskusi diperoleh refleksi sebagai berikut: Secara garis besar guru sudah menggunakan metode driil dan kelompok dalam pembelajaran dengan baik. Guru sudah melibatkan siswa dalam proses pembelajaran dan perannya sudah tidak terlalu dominan. Dilihat dari hasil evaluasi belajar yang dicapai siswa pada siklus2 pertemuan ketiga, tingkat ketuntasan klasikal sudah memenuhi kriteria keberhasilan. Hal tersebut terbukti dari semua siswa kelas VI SD Negeri I Badran yang terdiri dari 30 (tiga puluh) siswa dapat lulus Kriteria Ketuntasan Minimum (KKM) dengan nilai rata-rata 92,00.Dengan demikian proses perbaikan pembelajaran dapat dikatakan sudah berhasil. Selanjutnya hasil dari refleksi pada siklus 2 ini peneliti pergunakan dalam penyusunan laporan penelitian tindakan kelas.

Berdasarkan dari hasil penelitian yang dilakukan pada mata pelajaran matematika, berikut merupakan deskripsi data keseluruhan dari penelitian yang dilakukan.

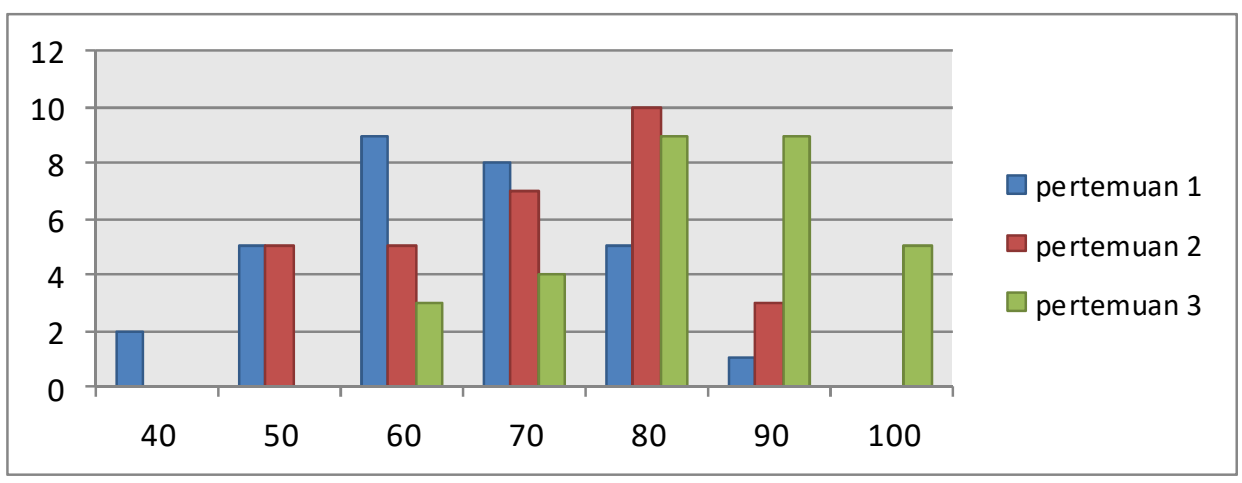


Gambar 2

Diagram Nilai Tes Formatif siklus I

Dari data diagram pada tahap siklus 1 pertemuan pertama nilai minimum mata pelajaran matematika 40 dan nilai maksimum adalah 90 dengan rata - rata kelas 64,00, sedangkan pada pertemuan kedua nilai minimum 50 dan nilai maksimum 90,dengan rata - rata kelas 70,33 dan pada pertemuan ketiga ini nilai minimum mendapatkan nilai 60, selanjutnya nilai maksimum sebesar 100 dan nilai rata-rata sebesar 83,00 .

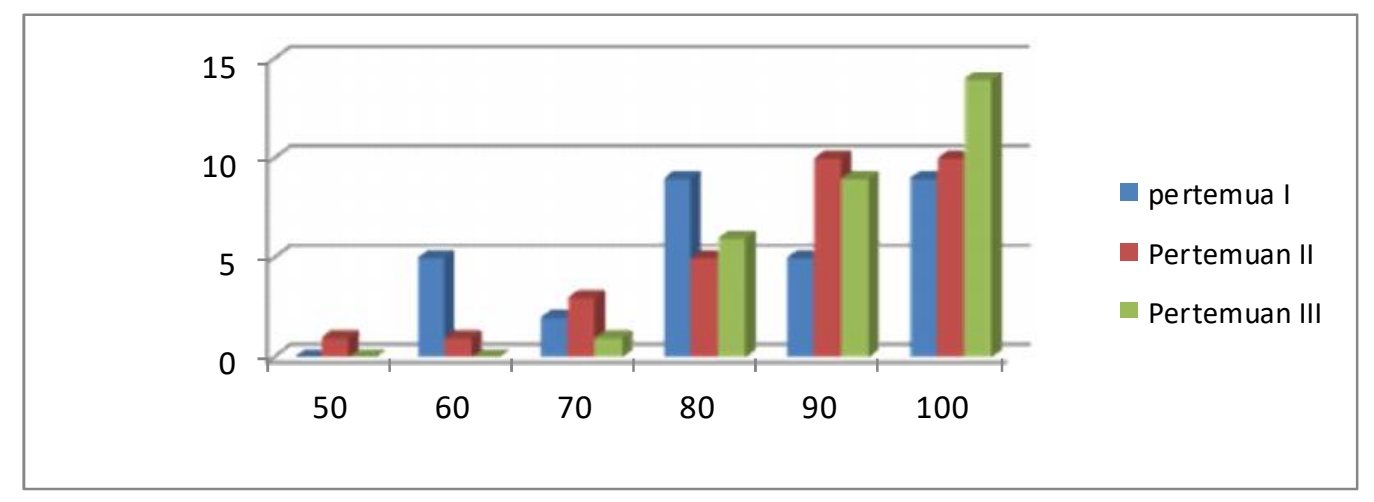

Gambar 3

Diagram Nilai Tes Formatif siklus II

Berdasarkan diagram diatas dapat diketahui untuk nilai minimum pada pelajaran matematika tahapan siklus II pada pertemuan pertama nilai terendah 60 dan nilai tertinggi 100 dengan rata - rata kelas 83,33, sedangkan pada pertemuan kedua nilai terendah 50 dan nilai tertinggi 100 dengan rata rata kelas 87,33 sedangkan pada pertemuan ketiga nilai terendah 70 dan nilai tertinggi 100 dengan rata - rata nilai 92,00. Hal ini membuktikan bahwa dalam pelaksanaan siklus yang ke-II ini setidaknya dapat difahami dan dimengerti oleh siswa. Pola-pola pemberian materi yang peneliti kajikan disini juga sangat berpengaruh terhadap rencana pelaksanaan pembelajaran yang peneliti kaji. Untuk lebih jelasnya pada rencana pelaksanaan pembelajaran dapat dilihat pada daftar lampiran siklus II mata pelajaran matematika.

Sebelum melaksanakan siklus I, peneliti melakukan survei awal untuk mengetahui kondisi yang ada di lapangan. Peneliti menemukan bahwa hasil belajar mengubah pecahan biasa menjadi persen serta sebaliknya hasil belajar di SD Negeri I Badran rendah.Kemudian peneliti berkolaborasi dengan observer untuk mengatasi masalah tersebut dengan metode motode Drill dan Diskusi Kelompok. Kemudian peneliti menyusun rencana untuk siklus I. Siklus I mengerjakan soal - soal yang berhubungan dengan materi mengubah pecahan dengan tugas kelompok dan Drill ternyata hasil belajar dan hasil ketuntasan meningkat. Pada siklus II dilaksanakan untuk mengatasi kelemahan atau kekurangan pada siklus I. Selama siklus II ada perubahan yang signifikan walaupun sedikit kelemahan dan ternyata hasinya lebih baik jika dibandingkan dengan siklus sebelumnya. Hal ini dimungkinkan siswa lebih mudah menentukan dan memahami konsep-konsep yang sulit dengan mendiskusikan bersama temannya. Siswa lebih termotivasi dan antusias.

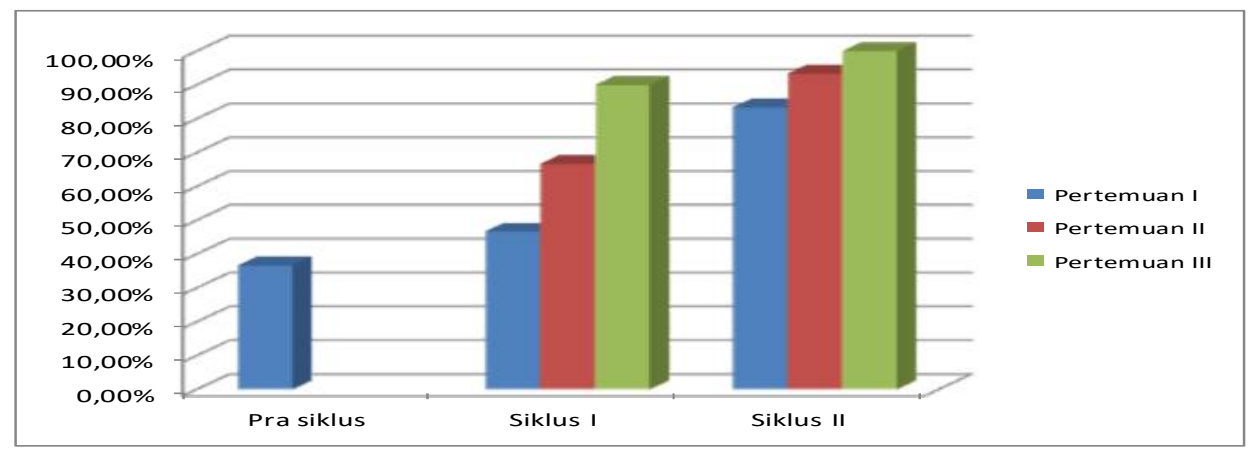


Upaya Meningkatkan Hasil Belajar Matematika Melalui Metode Drill Dan Diskusi Kelompok Pada Siswa Kelas VI SD

\section{Gambar 4}

Hasil Ketuntasan Pembelajaran Matematika

Diagram di atas menunjukkan ketuntasan hasil belajar siswa dari kondisi awal, siklus I, dan siklus II. Sebelum diadakan perbaikan dari jumlah 30 siswa yang tuntas belajar dengan KKM 70 hanya 11 siswa, dengan ketuntasan belajar 36, 66\%. Setelah diadakan perbaikan pembelajaran pada siklus I pertemuan pertama, yang tuntas ada 14, prosentase ketuntasan $46,67 \%$. Pertemuan kedua siswa yang tuntas 20, prosentase ketuntasan 66,67\%. Pertemuan ketiga siswa yang tuntas ada 27 prosentase ketuntasan $90,00 \%$. Perbaikan pembelajaran Siklus 2 hasil belajar siswa lebih terfokus pada tanya jawab dan belajar kelompok lebih dimaksimalkan. Ini terbukti pada pertemuan pertama yang tuntas 25 prosentase ketuntasan $83,33 \%$. Pertemuan kedua yang tuntas 28 , prosentase ketuntasan $93,33 \%$, pertemuan ketiga yang tuntas 30 , prosentase $100 \%$.

\section{Pembahasan}

Temuan penelitian ini sejalan dengan hasil penelitian Elypita Elly (2013) yang membahas tentang Peningkatan Kemampuan Berbicara melalui Metode Drill pada pelajaran Bahasa Indonesia Kelas IV Sekolah dasar Usaba Sepotong. Selain itu juga didukung penelitian yang dilakukan Erny Susilowati, Sigit Santoso, Nurhasan Hamidi (2013); Penggunaan Metode Pembelajaran Drill sebagai Upaya Meningkatkan Prestasi Belajar Akuntasi. Demikian juga hasil penelitian Mundasah (2016) tentang metode drill, metode drill dapat meningkatkan hasil belajar kerena memiliki kelebihan seperti berikut: 1) bisa digunakan untuk memperoleh kecakapan motoris seperti menulis, melafalkan huruf, membuat dan menggunakan alat-alat; 2) bisa digunakanmemperoleh kecakapan mental seperti dalam perkalian, penjumlahan, pengurangan, pembagian, tanda-tanda/simbol, dan sebagainya; 3) dapat membentuk kebiasaan dan menambah ketepatan dan kecepatan pelaksanaan. Selain itu, temuan penelitian ini juga sejalan dengan temuan penelitian Hal ini relevan dengan penelitian yang dilakukan Herman Joseph Siswandi (2006) dengan judul Meningkatkan Keterampilan Berkomunikasi melalui Metode Diskusi Panel dalam Mata Pelajaran Bahasa Indonesia di Sekolah Dasar. Metode diskusi kelompok bisa meningkatkan hasil belajar karena menurut Rustaman, dkk. (Afidah, I. N., Santosa, S., \& Indrowati, M., 2012) memiliki kelebihan antara lain merangsang keberanian dan kreativitas siswa bertukar pikiran dengan teman; Kelebihan yang lain yaitu menerima dan menghargai pendapat orang lain, pada akhirnya kegiatan diskusi akan melatih siswa belajar bertangung jawab terhadap hasil pemikiran bersama.

\section{SIMPULAN DAN SARAN Simpulan}

Berdasarkan tujuan penelitian dan uraian pembahasan dan hasil penelitian, dapat simpulan sebagai berikut:1). Perbaikan pembelajaran matematika melalui metode driil dan diskusi kelompok sangat tepat diberikan kepada siswa, hal ini akan memberikan kesempatan yang lebih kepada siswa dalam melakukan pembelajaran 2). Melalui metode drill dan diskusi kelompok yang diberikan kepada siswa memberikan sumbangan yang sangat tepat, hal ini dapat diketahui dari data kenaikan atau peningkatan nilai yang didapat siswa dari tahapan per siklusnya mengalami perbedaan yang signifikan.

\section{Saran}

Berdasarkan tujuan penelitian dan uraian pembahasan dan hasil penelitian, dengan metode Driil dan Kelompok Belajar dapat disimpulkan Dalam kegiatan pembelajaran kerap kali muncul berbagai masalah, salah satu permasalahan yang sering dihadapi adalah rendahnya tingkat pemahaman dan penguasaan materi yang diterima siswa. Oleh sebab itu hendaknya: 1).Guru lebih memperhatikan Rencana Pelaksanaan Pembelajaran yang akan diberikan kepada siswa 2). Guru hendaknya menyusun program pembelajaran yang disesuaikan materi pembelajaran siswa serta memberikan evaluasi baik evaluasi yang bersifat klasikal maupun individual.3).Guru hendaknya memberikan kesempatan yang lebih kepada siswa dalam memecahkan permasalahan pembelajaran, hal ini secara tidak langsung akan membuka pola berfikir siswa. 


\section{DAFTAR PUSTAKA}

Afidah, I. N., Santosa, S., \& Indrowati, M. 2012. Pengaruh penerapan Metode Socratic Circles disertai media gambar terhadap kemampuan berpikir kreatif siswa. Pendidikan Biologi, 4(3).

Anni, Catharina Tri, 2007. Psikologi Besar, Semarang: UNNES Press.

Dimyati dan Mudjiono. 2009. Belajar dan Pembelajaran. Jakart: PT Rineka Cipta.

Gagne, RM. 1989. Conditioning of Learning and Theory of Instruction.Fourth Edition. New York: CBS College Publishing.

Elypita Elly. 2013. Peningkatan Kemampuan Berbicara melalui Metode Drill pada pelajaran Bahasa Indonesia Kelas IV Sekolah dasar Usaba Sepotong. Jurnal Untan. Vol 2, N 8.

Erny Susilowati, Sigit Santoso, Nurhasan Hamidi. 2013. Penggunaan Metode Pembelajaran Drill sebagai Upaya Meningkatkan Prestasi Belajar Akuntasi. Jurnal Pendidikan UNS, Vol 1, No 3, $(1-10)$

Herman Joseph Siswandi. 2006. Meningkatkan Keterampilan Berkomunikasi Melalui Metode Diskusi Panel dalam Mata Pelajaran Bahasa Indonesia di Sekolah Dasar. Jurnal Pendidikan Penabur No.07/Th.V/Desember 2006, 24 - 35.

Herman. 1990. Mengajar Belajar Matematika. Jakarta: Depdikbud. http://penelitiantindakankelas. blogspot.com/2009/03/sekilas-meninjau modelpembelajaran.html/didownload 20-10-2009.

Mulyati, S. 2016. Upaya Meningkatkan Hasil Belajar Matematika Melalui Metode Diskusi Berbantuan Media Bagan Pecahan di Kelas III SDN Kalisari 1. Jurnal Pendas, 3(1), 13-19.

Mundasah. 2016. Peningkatan Ketrampilan Menghitung Bilangan Dua Angka Menggunakan Metode Drill. Jurnal Penelitian Pendidikan Indonesia (JPPI), 1(1).

Sadiman, Arif S., dkk. Media Pendidikan Pengertian, Pengembangan dan Pemanfaatannya. Jakarta: PT Raja Grafindo Persada dan Pustekkom Dikbud.

Sari, Noviyana, and Maryatun. 2016. Pengaruh Penggunaan Metode Drill Terhadap Hasil Belajar Akuntansi Kelas X Semester Genap SMK Negeri 1 Metro Tahun Pelajaran 2015/ 2016. PROMOSI (Jurnal Pendidikan Ekonomi) 4.2 (2016).

Sujana, Nana. 2005. Penilaian Hasil Proses Belajar Mengajar. Bandung: PT Remaja Rokdakarya.

\section{Profile Singkat}

Erlyn Juniati, S.Pd. Menyelesaikan studi S1 PGSD UT. Kepala Sekolah SD Negeri 4 Kemloko kecamatan Kranggan Kabupaten Temanggung. Prestasi yang pernah diraih menjadi Juara 1 Guru berprestasi tingkat kabupaten tahun 2013. 